\title{
PELAGIC ENVIRONMENT IN THE WESTERN PART OF JAKARTA BAY
}

\author{
by \\ ANUGERAH NoNTJi ${ }^{1)}$ and IMAM SUPANGAT ${ }^{1}$ )
}

ABSTRACT

Seven stations in the western part of Jakarta Bay were occupied monthly from June 1974 to June 1975. Monthly variations of several hydrological and biological properties of the pelagic environments are described. Rainfall over the hinterland of Jakarta plays important role in lowering the salinity in the bay. On the other hand the phosphate content is more closely associated with the rainfall over Jakarta. The main source of phosphate is likely to come from the result of urban activities in Jakarta. There is a fair corespondence in annual fluctuation between phosphate and phytoplankton chlorophyll. Annual mean of properties at each station shows that from the shore outward the values of phosphate, phytoplankton chlorophyll, and zooplankton volume decreased while of salinity and transparency increased. Interrelationships among several factors are discussed.

\section{INTRODUCTION}

The importance of Jakarta Bay as a marine environment lies on the fact that it is used for many purposes: transportation, fishery, tourism and recreation. A lot of garbage and other waste from the capital Jakarta also find their ways into the bay. There has been increasing anxiety that the fast growing population of Jakarta with all its activities might produce negative impact on the ecology of the bay. On the other hand our basic knowledge on the environment of the bay is still very meagre. Very few hydro-biological studies have been made in the region.

VERWEY (1929) in connection with his coral study made some observations on the transparency and oxygen at Pulau Air Besar. VerstAPPEN (1953) also made some observations on transparency and salinity in relation to his geomorphological study on the bay, although they were limited to only several months. SOERIAATMADJA (1956) gave a short account on the salinity fluctuation in the area off Jakarta Bay. Description of zooplankton distribution in a region north of the bay was given by PRASENO \& ARINARDI (1974). In the southern part of Seribu Islands, about northwest of Jakarta Bay, KASTORO \& BIROWO (1974) reported the result of a monthly observation on temperature and salinity, while HUTOMO (1975) studied the seasonal variation of the phytoplankton. A preliminary pollution study of

1) National Institute of Oceanology - Indonesian Institute of Sciences (LON - LIPI), Jakarta. 


\section{ANUGERAH NONTJI \& IMAM SUPANGAT}

the aquatic environment of Jakarta was carried out by BILAL et al (1974). Their observations in the bay, however, were limited to about one kilometer from the shore.

The present study is an attempt to get a further insight on the variation of the pelagic environment in Jakarta Bay and is limited only along a line on the western part.

\section{DESCRIPTION OF THE AREA}

Jakarta Bay is shallow, generally less than $30 \mathrm{~m}$. Its bottom is sloping from the shoreline northward toward the Jawa Sea. The isobaths 5, 10, and $20 \mathrm{~m}$ run almost parallel to the shoreline (Fig. 1). The mouth opening of the bay is about 22 miles in breadth and the southernmost extension of the shoreline is about 10 miles from the line connecting both points limiting the bay.

In the central part of the bay as well as in the western part, several small coral islands are found. Northwest of the bay lies a long chain of coral islands (Seribu Islands) extending in about southnorth direction.

Many rivers discharge their waters into the bay (Fig. 2), the important ones being (a) Citarum River, and its branches forming extensive delta regions east of the bay, (b) Bekasi River, (c) Ciliwung River, passing through the harbour of Sunda Kelapa, and (d) Angke River.

Because Jakarta Bay opens directly toward the Jawa Sea, its hydrologi-cal condition is also affected by the latter. The most important factor governing the hydrological condition of the Jawa Sea is the monsoonal changes. The east monsoon (June to August) is usually dry and west going current prevails. The west monsoon (December to February) is rainy with prevailing east going current. The rest of the year represents the transitional periods which is usually accompanied with lower wind force.

\section{MATERIALS AND METHODS}

An oceanological study was carried out at the western part of Jakarta Bay covering seven stations and extending along the longitude $106^{\circ} 47^{\prime} \mathrm{E}$ and about 1.5 to 13 miles from the southern shoreline (Fig. 1). Monthly observations were made with a small vessel "Mutiara IV" from June 1974 to June 1975. The depths at the stations are gradually deepening from about $10 \mathrm{~m}$ at station 1 to about $32 \mathrm{~m}$ at station 7 . Distance between successive 
PELAGIC ENVIRONMENT IN JAKARTA BAY

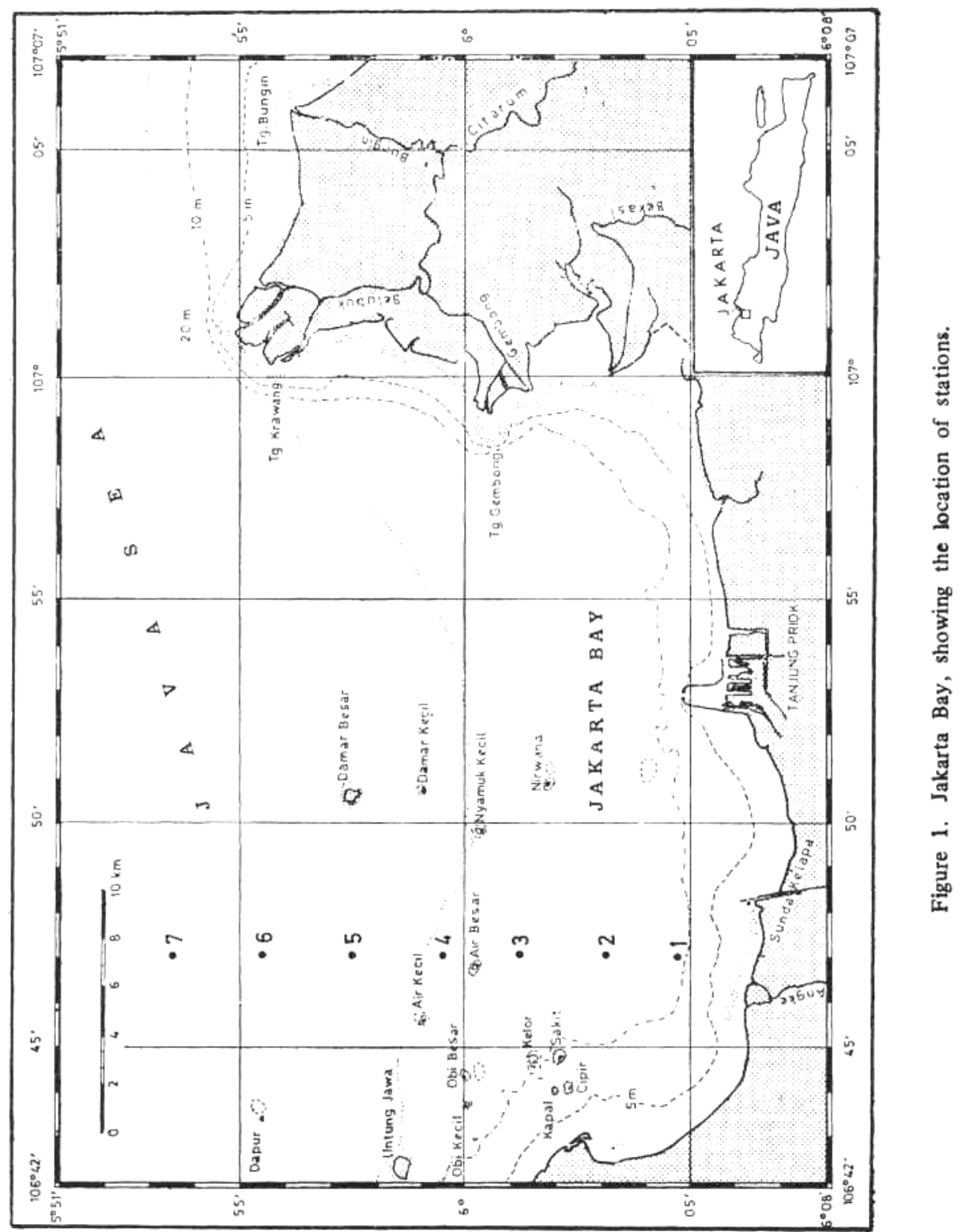




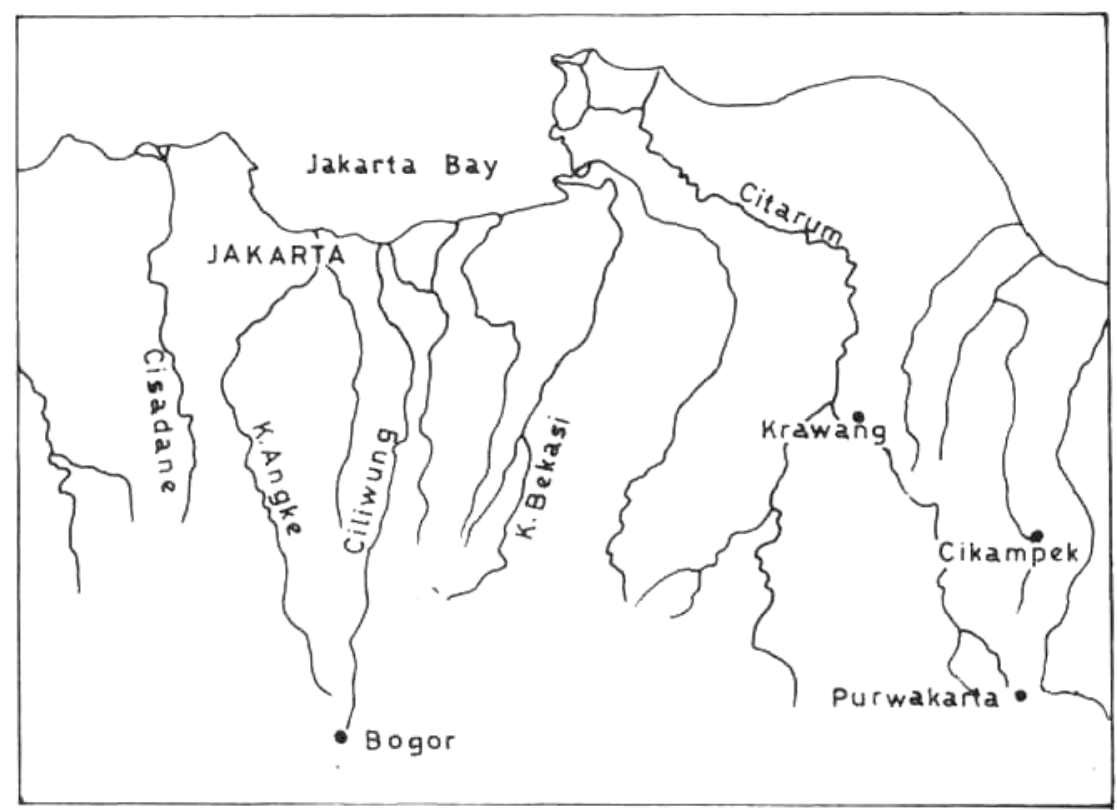

Figure 2. River system around Jakarta.

stations is about two miles. Station 1 lies somewhat between the mouth of Ciliwung and Angke Rivers.

Hydrological sampling was made using Nansen bottles from the surface and several subsurface layers down to the depth just above the bottom. Water temperature was measured with paired reversing thermometers. Salinity was determined following the classical Knudsen titration, standardized against Copenhagen "normal water" Dissolved oxygen content was determined with Winkler titration as described in U.S. NAVY HYDROGRAPHIC OFFICE (1959). Oxygen saturation was calculated following RICHARDS \& CORWIN (1956). Dissolved inorganic phosphate was determined according to the method of STRICKLAND \& PARSONS (1968) using a "Spectronic-20" spectrophotometer. For transparency measurement a secchi disk was used.

Water sample for the determination of phytoplankton chlorophyll was collected with Van Dorn bottles from several layers with depth intervals of $5 \mathrm{~m}$. Millipore filter HA (pore size $0.45 \mathrm{JU}$ ) with diameter $47 \mathrm{~mm}$ was used for this purpose and extraction was made with $90 \%$ acetone. "Spectronic-20" was used for extinction readings and followed with calculation using the equation suggested by PARSONS \& STRICKLAND (1963). 


\section{PELAGIC ENVIRONMENT IN JAKARTA BAY}

For zooplankton sampling a Norpac net (diameter $45 \mathrm{~cm}$, mesh 0.33 $\mathrm{mm}$ ) with flow meter mounted on the centre of the mouth was used vertically from near the bottom to the surface. Displacement volume was measured according to WICKSTEAD (1965).

\section{RESULTS AND DISCUSSION}

\section{Temperature}

Monthly mean temperature at the surface varied between 28.28 and $30.47^{\circ} \mathrm{C}$ with an annual mean $29.18^{\circ} \mathrm{C}$ (Fig. 3). Minima occurred in July $\left(28.67^{\circ} \mathrm{C}\right)$, September $\left(28.81^{\circ} \mathrm{C}\right)$ and December - February (28.54 $28.28^{\circ} \mathrm{C}$ ). After a slight increase in August two maxima were found, respectively in November $\left(30.04^{\circ} \mathrm{C}\right)$ and the primary one in April $\left(30.47^{\circ} \mathrm{C}\right)$.

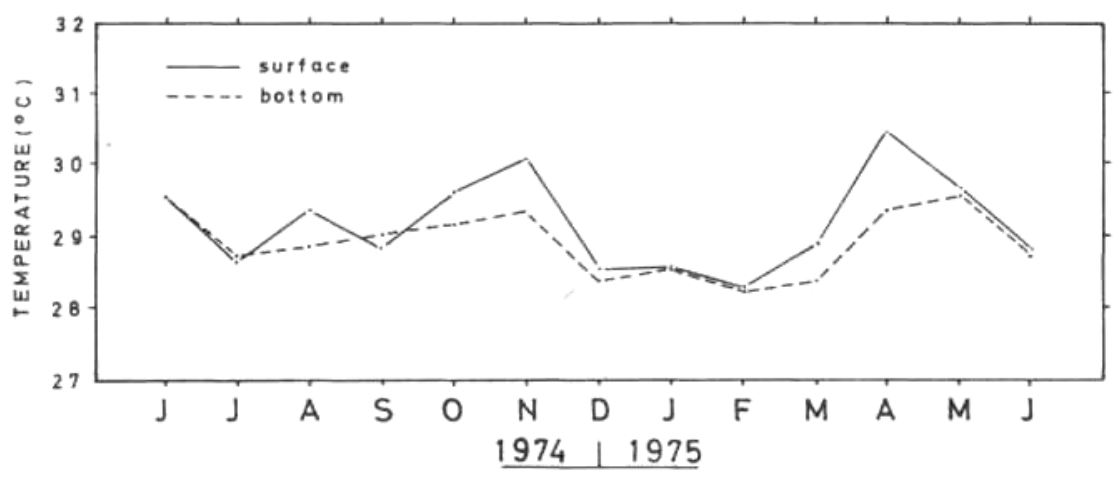

Figure 3. Monthly fluctuation of temperature.

The maxima occurred during the change of the monsoon when the wind velocities are generally low. The minima occurred during the strong development of both the west and the east monsoons. At these periods the force of the wind is comparatively high, thereby inducing increased evaporation and resulting in lower temperature. In the west monsoon this situation is usually superimposed with the high rainfall and lower solar radiation. The comparatively low temperature in September 1974 and February 1975 coincided with the maxima of rainfall over Jakarta. During both of these months the rainfall over Jakarta was considerably higher than standard normal (Fig. 4). The low value in July (when rainfall over Jakarta was at its minimum) may be explained by the high evaporation. 
ANUGERAH NONTJI \& IMAM SUPANGAT

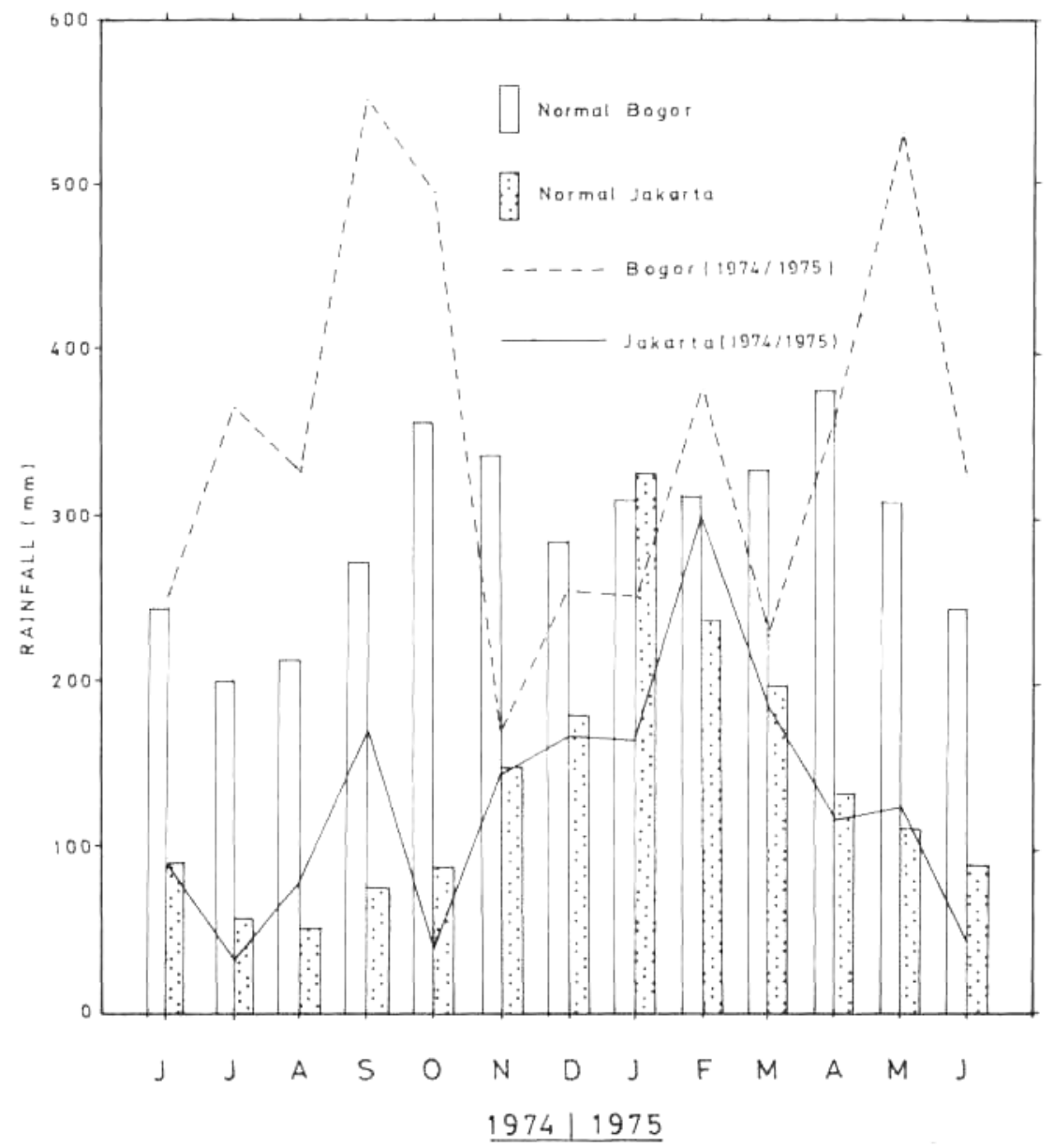

Figure 4. Rainfall over Jakarta and Bogor.

Compared to the result of the surface temperature measurement in the neighbouring region in the southern part of Seribu Islands (KASTORO and BIROWO 1974) it is clear that the present result shows considerable similarities in the basic pattern of monthly variation. The annual mean, however, shows that the temperature in Jakarta Bay is somewhat higher (Jakarta Bay $29.18^{\circ} \mathrm{C}$, Southern Seribu Islands $28.92^{\circ} \mathrm{C}$ ) and with greater range $\left(2.19^{\circ} \mathrm{C}\right.$ and $1.38^{\circ} \mathrm{C}$ respectively) which probably can be attributed to the proximity of the land mass.

Vertical distribution of temperature in Jakarta Bay as observed during the present investigation indicates that the temperature of the bottom water 


\section{PELAGIC ENVIRONMENT IN JAKARTA BAY}

was generally slightly lower than that at the surface (Fig. 3). However, if a tolerance of $1{ }^{\circ} \mathrm{C}$ can be admitted for the variation in the upper water in dealing with the homogeneous layer (WYRTKI 1961) then the temperature of the water column along the section was almost homogeneous throughout the year. A slight thermal gradient of the water developed in April which coincided with the development of a strong vertical salinity gradient.

\section{Salinity}

The monthly fluctuation of surface salinity is shown in Figure 5 which varied between 30.07 and $32.93 \%$ o and with annual mean $31.36 \%$. The salinity from June (31.25\%o) varied only a little until August. This was followed with a sudden drop in September (30.25\%), after which it rose again to maximum in November (32.93\%). Decreasing values then followed (with a slight increase in January) until minimum was reached in April (30.07\%o). The low salinity persisted until May and then began to increase again in the next month.

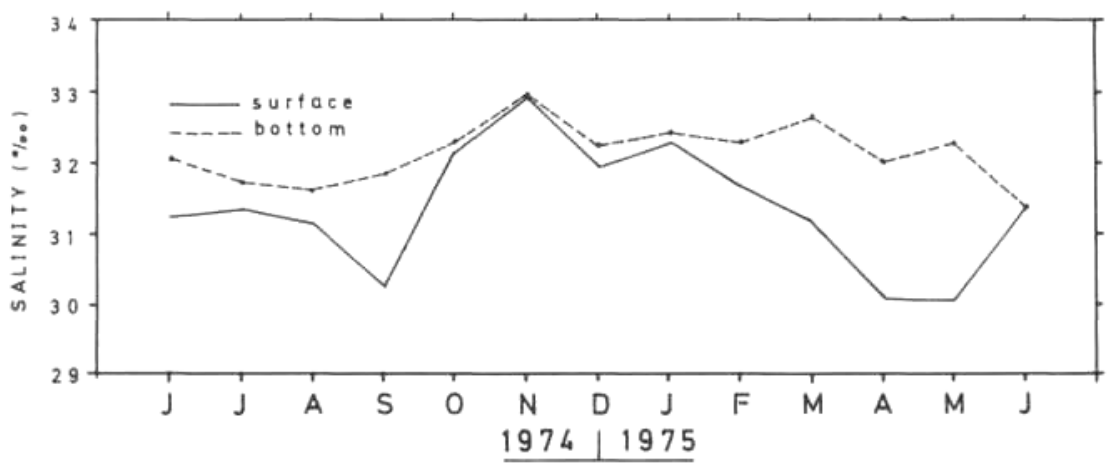

Figure 5. Monthly fluctuation of salinity.

Salinity in the bottom layer was generally higher. In September a comparatively great vertical salinity gradient occurred in the water column. In November, however, this condition was changed and a uniform salinity was found in the whole water column. During the following months the vertical salinity gradient began again to develop until in April a very strong stratification occurred. Successive stages from the well mixed water in November to a distinct stratification in April is best illustrated in a cross sectional view as shown in Figure 6. When the water was strongly stratified as in April, the low salinity water (less than $31.0 \%$ ) occurred only in a thin surface layer of less then $5 \mathrm{~m}$. 
ANUGERAH NONTJI \& IMAM SUPANGAT

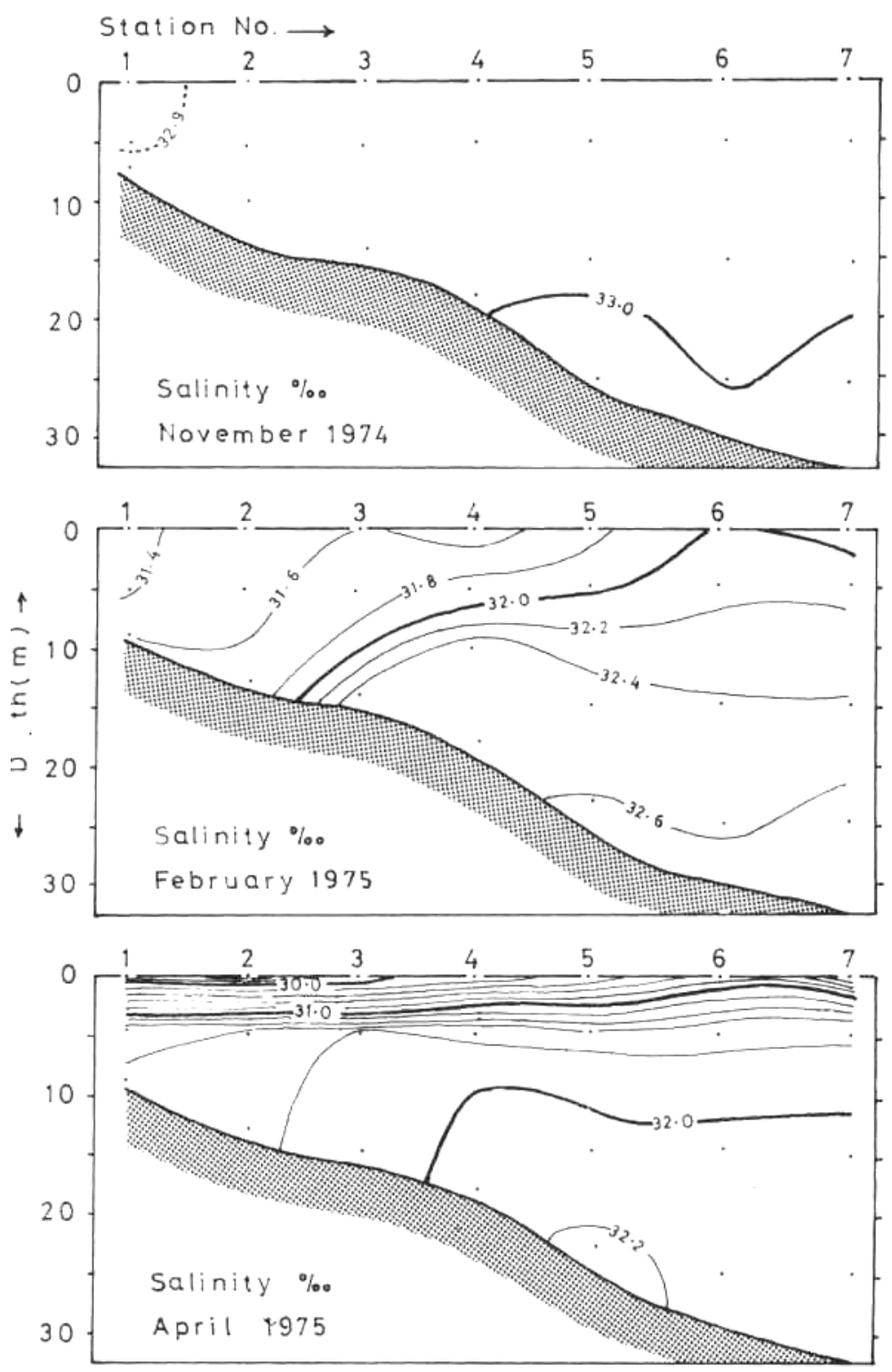

Figure 6. Salinity cross section in November 1974, Februari and April 1975.

7

6

PELAGIC ENVIRONMENT IN JAKARTA BAY

The most important factor governing the lowering of surface salinity in an estuarine area is the inflow of fresh water from the rivers. Greater effect of the river discharge is usually expected when rainfall on the land is also high. However, if a simple correlation is made between the monthly total rainfall over Jakarta and the monthly mean surface salinity in Jakarta Bay, a very low correlation was found $(\mathrm{r}=0.04$, Table 1$)$. Considering that the most important rivers discharging their water in the study area are Angke and 
Ciliwung rivers, an examination was also made on the contribution of rainfall over the hinterland area upstream. Rainfall data from meteorological station in Bogor (Darmaga) was used as an example (Fig. 4). During the study period the annual mean of monthly total rainfall over Bogor was almost three times higher than that over Jakarta, being 345 and $127 \mathrm{~mm}$ respectively. It appeared that significant negative correlation was found between monthly total rainfall over Bogor and the monthly mean surface salinity in Jakarta $(r=-0.59)$. This evidence indicates that the rainfall over the hinterland of Jakarta is the major contributor to the dilution of seawater in Jakarta Bay through the agency of the rivers. However, it has a relatively smaller contribution to the phosphate content in the Jakarta Bay as will be discussed later.

TABLE 1. Correlation between rainfall to salinity and phosphate,

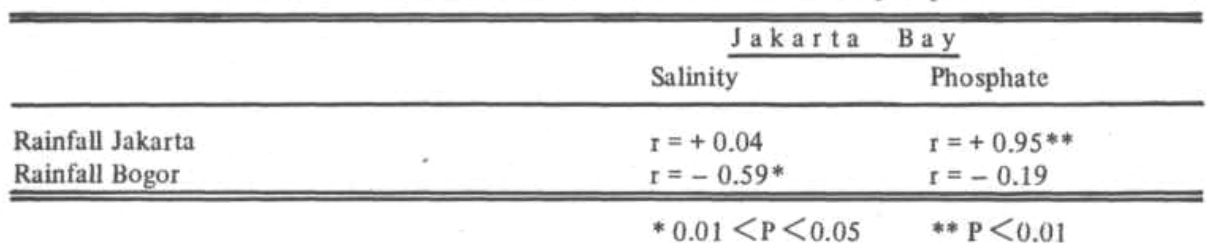

The minimum salinity in September and again in April - May coincided with the high rainfall over Jakarta and Bogor. The occurrence of maximum surface salinity in November $(32.93 \%$ ) may be explained by the intrusion of high salinity water from the Flores Sea coming through the southern part of the Java Sea. SoeriaAtmadja (1956) showed that the westward movement of this high salinity water reaches its farthest extension to the region off Jakarta Bay in November.

Compared to the work of SOERIAATMADJA (1956) for the salinity in the region off Jakarta Bay, it is found that the present result keep the similar pattern of fluctuation despite some minor differences. Our results, for instance, show a tendency of shifting the minimal values toward the later 


\section{ANUGERAH NONTJI \& IMAM SUPANGAT}

part of the year. But on the other hand our primary maximum in November is similar to SOERIAATMADJA's (1956) as well as that of the region in the southern part of Seribu Islands as observed by KASTORO \& BIROWO (1974). The distribution of surface salinity and other properties as a function of distance from the shore is plotted in Figure 7 where it can been seen that the annual mean of surface salinity at the station nearest to the shore was the lowest (30.82\%o ) and gradually increased toward the outermost station $(31.78 \%)$.

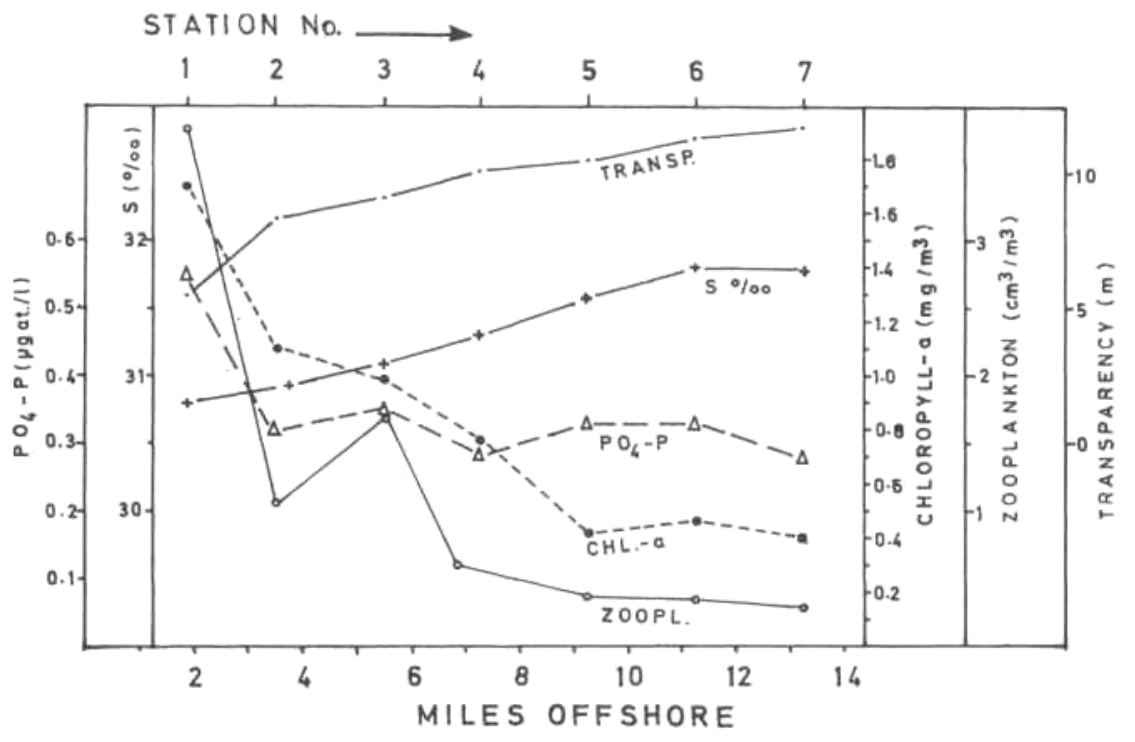

Figure 7. Annual mean of properties at the seven stations.

\section{Phosphate}

During the study period the annual mean of surface phosphate was 0.35 $\mathrm{Mg}$ at.P/1 with monthly variation between 0.18 and $0.88 / \mu \mathrm{g}$ at.P/1 (Fig. 8). Three peaks were observed namely in September, November, and the greatest one in February. Minima were found in June - July, October, December and April. Bottom phosphate was usually higher than that at the surface except in September and March.

It is commonly accepted that the major source of nutrients in the estuarine area comes from the river. To have a better look on this aspect a simple correlation was also made between the rainfall over Jakarta and its 
PELAGIC ENVIRONMENT IN JAKARTA BAY

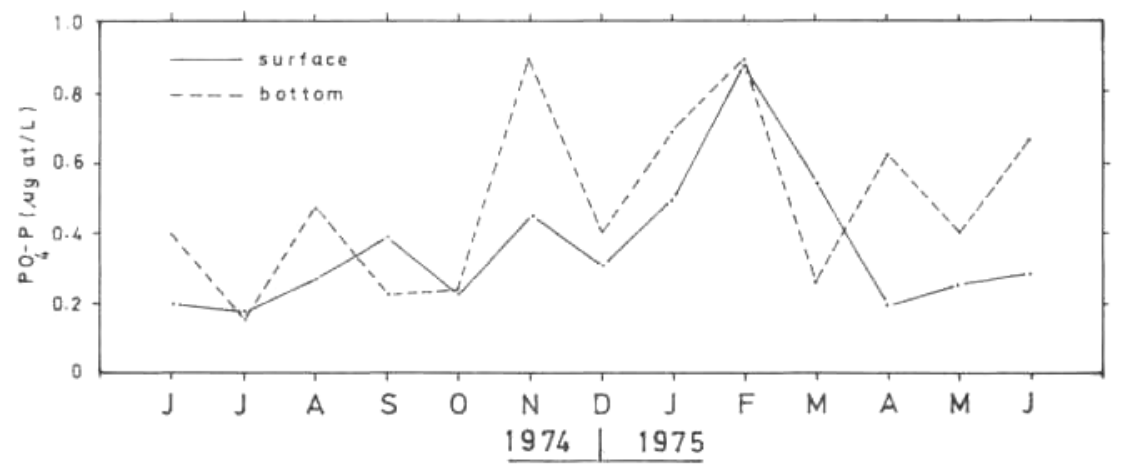

Figure 8. Monthly fluctuation of phosphate

hinterland (Bogor) and phosphate content in the Jakarta Bay. Table 1 shows that while rainfall from Bogor is the major contributor to the lowering of surface salinity in the bay, it has only a relatively minor role as a phosphate contributor. On the contrary, the rainfall over Jakarta has minor impact on the decrease of salinity in the bay but it has highly significant positive correlation with the phosphate $(\mathrm{r}=+0.95)$. This suggests that the major source of phosphate discharge by the rivers into the bay has its origin in the city of Jakarta. This is not surprising as the urban area usually produces a great amount of phosphate and other nutrients. In the rural area the cyclical process of organic and inorganic matter is going in a better condition compared to that in the urban area where the cyclus is much disturbed. SOEMARWOTO (1973) has shown for instance that in Bandung, West Jawa, the phosphate content in the river in the upstream part of the city will be doubled after passing the urban area. In Jakarta the rivers and streams in fact have been severely polluted and contain high values of phosphate as has been shown by BILAL et al. (1975). The volume of solid wastes from Jakarta, population 5,000,000 people, is estimated about $7200 \mathrm{~m}^{3} /$ day and of which $1800 \mathrm{~m}^{3} /$ day find their way into the aquatic environments. In term of origin the market waste comprises $9.7 \%$, industries $6.9 \%$. household $72.2 \%$ and others $11.2 \%$ (PUTL \& DKI 1973). The accumulation of phosphate and other nutrients occurs when natural aquatic environments are unable to assimilate what is dumped there by the heavily populated metropolitan. When rain falls over Jakarta it is natural that much greater amount of phosphate will find its way into the rivers, canals, streams and ultimately into the bay. Thus the rainfall over Jakarta, despite the lesser amount of water it contributes into the bay compared to that from Bogor, is an important factor in the enrichment of phosphate. 


\section{ANUGERAH NONTJI \& IMAM SUPANGAT}

From stations monthly occupied in the bay it can also be seen that the annual mean at the station nearest to the shore (station 1) has the greatest value $(0.56 / \mu \mathrm{g}$ at.P/1) and decreasing offshore until at the outermost station (station 7) it is $0.28 \mathrm{Mg}$ at.P/1 (Fig. 7).

\section{Oxygen}

Annual mean of dissolved oxygen at the surface was $4.24 \mathrm{ml} / 1$ which varied between the minimum $3.9 \mathrm{ml} / 1$ in May and maximum $4.72 \mathrm{ml} / 1$ in December. Monthly means at the bottom were lower than that at the surface. Slight vertical gradients occurred in August and April (Fig. 9).

In term of oxygen saturation the mean monthly surface values varied from $89.26 \%$ in May and $107.26 \%$ in December. In most cases the oxygen saturation was lower than $100 \%$.
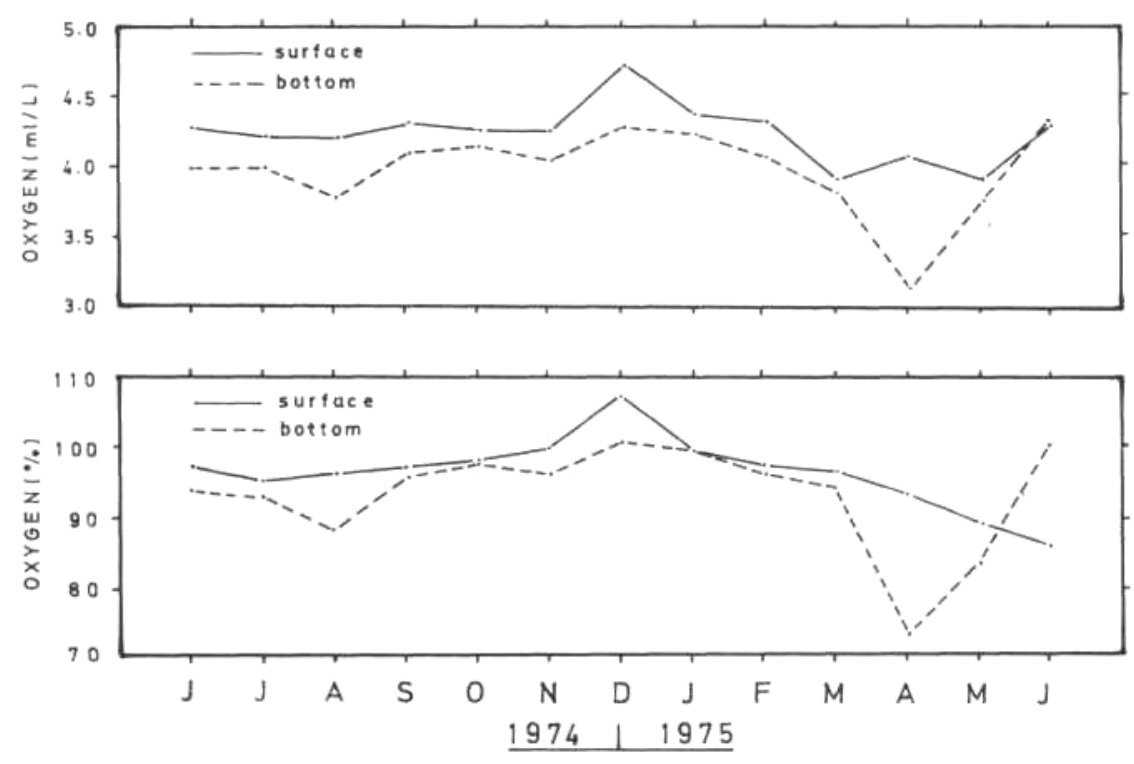

Figure 9. Monthly fluctuation of oxygen.

\section{Tranparency}

Fluctuation of the monthly mean tranparency in term of secchi disk depth is shown in Figure 10. Annual mean for all stations was $9.27 \mathrm{~m}$. Maxima were found in October $(14.6 \mathrm{~m})$ and March $(11.4 \mathrm{~m})$ while minima in August $(8.4 \mathrm{~m})$ and December $(6.6 \mathrm{~m})$. The maxima occur within the transition 
PELAGIC ENVIRONMENT IN JAKARTA BAY

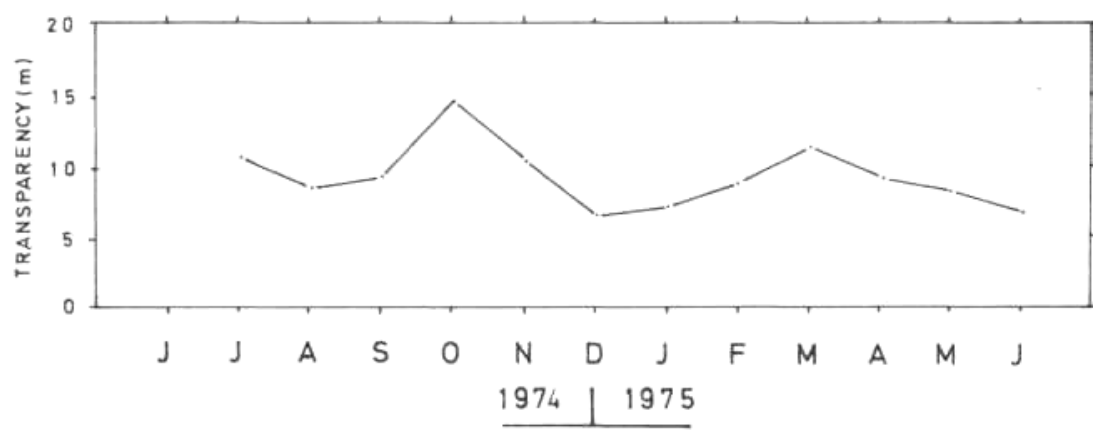

Figure 10. Monthly fluctuation of transparency.

periods where calm sea is common and the minima when the sea is generally rougher in the full development of the monsoon. The annual mean at the station nearest to the shore was only $5.04 \mathrm{~m}$ and increasing offshore until at the outermost station it was $11.8 \mathrm{~m}$ (Fig. 7).

VERWEY (1929) made tranparency measurement close to Pulau Air Besar near our station 4, and gave results which varied between 3.5 to $6.5 \mathrm{~m}$. VERSTAPPEN (1953) also made transparency measurement in Jakarta Bay and studied its relation to the salinity distribution. He found that only at the river mouth is the low transparency accompanied with low salinity which is a consequence of river silt. Everywhere else along the coast the low transparency occurs with a fairly normal salinity and this according to his account, must have been brought about by silt whirled up from sea bottom by surf.

Transparency of the water is of great importance to the productivity study of a water body as it can be used as an indicator of the depth of the euphotic zone (the depth reached by $1 \%$ of the ambient radiant energy). It is common practice to primary productivity workers to estimate the depth of euphotic zone by multiplying the secchi disk depth by 3 , despite some minor differences applied by different workers (MCGILL 1973). An inspection of annual mean at the seven stations (Fig. 7) and bearing in mind the bottom depth at each station one can find that by using a factor of 3, the whole water column in Jakarta Bay may be regarded as productive.

\section{Phytoplankton chlorophyll}

The content of chlorophyll-a in a certain volume of sea water can be used to estimate either the living matter in the phytoplankton or the rate of phytoplankton production through the photosynthetic process (STRICKLAND 
1960). A rapid chemical method for chlorophyll determination as used in the present study gives an annual mean for the surface layer being 0.84 $\mathrm{mg} / \mathrm{m}^{3}$. Monthly mean varied between 0.29 and $2.69 \mathrm{mg} / \mathrm{m}^{3}$. Three maxima were observed (Fig. 11) namely in July $\left(0.94 \mathrm{mg} / \mathrm{m}^{3}\right)$, November (1.19 $\left.\mathrm{mg} / \mathrm{m}^{3}\right)$ and the primary one in March $\left(2.69 \mathrm{mg} / \mathrm{m}^{3}\right)$. Minima occurred in September $\left(0.45 \mathrm{mg} / \mathrm{m}^{3}\right)$, December-January $\left(0.48-0.44 \mathrm{mg} / \mathrm{m}^{3}\right)$ and May $\left(0.29 \mathrm{mg} / \mathrm{m}^{3}\right)$.

Annual surface mean at each station (Fig. 7) shows that the greatest value was again nearest to the shore $\left(1.71 \mathrm{mg} / \mathrm{m}^{3}\right)$ followed with decreasing values further offshore until the three outermost stations (station 5,6 , and 7) they were more or less constant about $0.41-0.45 \mathrm{mg} / \mathrm{m}^{3}$. In the vertical distribution the depth of chlorophyll maximum occurred mostly either at the surface layer or near the bottom (Table 2). The latter may be partly due to the presence of dead and inactive chlorophyll from detrital material and stirred up sediment. Degraded forms of inactive chlorophyll (phaeopigments) could interfere with the spectrophotometric determination of chlorophyll because they absorb light in the same region of the spectrum as chlorophyll.

\begin{tabular}{|c|c|c|c|c|c|c|c|}
\hline $\begin{array}{lll}\text { Depth } \mathrm{m} & \text { Sta. No. } \\
\end{array}$ & 1 & 2 & 3 & 4 & 5 & 6 & 7 \\
\hline 0 & 7 & 8 & 5 & 5 & 3 & 4 & 3 \\
\hline 5 & - & 1 & 1 & 4 & 2 & 2 & 2 \\
\hline 10 & 6 & 4 & - & - & 1 & - & 1 \\
\hline 15 & & & 7 & 4 & - & - & - \\
\hline 20 & & & & & 7 & 4 & 3 \\
\hline 25 & & & & & & 3 & 2 \\
\hline 30 & & & & & & & 2 \\
\hline
\end{tabular}

The monthly fluctuation of phytoplankton chlorophyll appeared to have a fair correspondence with the fluctuation of phosphate (Fig. 11). The chlorophyll peak may coincide with the peak in phosphate (e.g. November) which may indicate the fairly rapid respons of phytoplankton growth to the availability of phosphate. On the other hand time lag may also be observed, for instance the highest chlorophyll peak in March was preceded by the highest phosphate peak in February. Similar relationship was also observed in Singapore waters (THAM 1953; CHUA 1970). This relationship, however, may be rather disturbed when zooplankton was found in relatively great abundance such as in September. The great abundance of zooplankton may 
PELAGIC ENVIRONMENT IN JAKARTA BAY

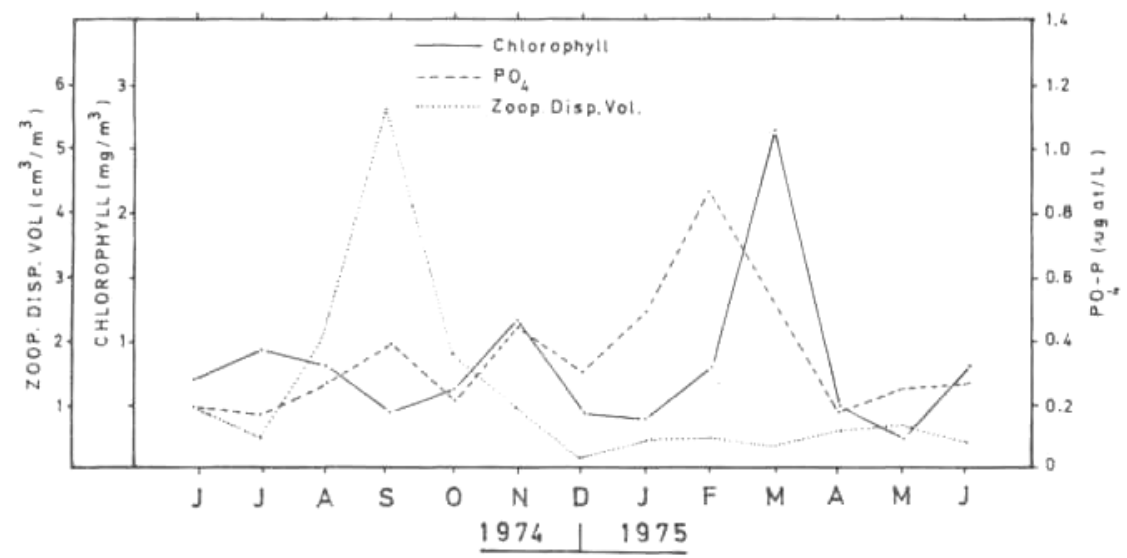

Figure 11. Monthly fluctuation of chlorophyll, phosphate and zooplankton volume.

have a consequence on the lowering of the amount of phytoplankton through the grazing pressure. The importance of grazing on the phytoplankton production has been explained by CUSHING (1958). Zooplankton may also play an important role on the recylcling of nutrients by way of zooplankton excretion and remineralization through bacterial activity. TRANTER (1973) stressed the importance of this recycling mechanism in the tropics.

The present study indicates that the highest zooplankton volume in September coincided with low chlorophyll and high phosphate (Fig. 11). Monthly observation of marine heterotrophic bacteria at the same location and period also indicates that the monthly mean of bacterial count reached its peak in September (SOEMINARTI THAYIB, personal communication). It is probable that the peak of phosphate in this month reflected the combine results of river runoff and the increase of the recycling process.

\section{Zooplankton volumes}

Monthly means of zooplankton volumes were usually lower than 1 $\mathrm{cm}^{3} / \mathrm{m}^{3}$ (Fig. 11). Higher values were found from the later part of the east monsoon (August to October) with a peak in September $\left(5.78 \mathrm{~cm}^{3} / \mathrm{m}^{3}\right)$. Copepod was generally the most important component.

The higher zooplankton volumes in the east monsoon was also observed in the western part of the Jawa Sea just outside of Jakarta Bay (PRASENO \& ARINARDI 1974). They revealed that in the east monsoon the zooplankton volumes were greater by more than twofold compared to that in the west monsoon. 


\section{ANUGERAH NONTJI \& IMAM SUPANGAT}

\section{CONCLUSION}

The pelagic environment of the western part of Jakarta Bay is much influenced by the monsoon. Rainfall plays an important role through its consequent water discharge by the rivers into the bay. Closer to the shore the values of salinity and transparency are low while phosphate, chlorophyll and zooplankton volumes are high.

The urban area of Jakarta is the major supplier of phosphate into the bay which is important for the growth of phytoplankton.

Many other aspects which may affect the pelagic ecosystem in the bay have not been understood clearly and still have to be learned, for instance the role of other nutrients besides phosphate, current pattern, mixing of the water etc. The qualitative changes of the phytoplankton and zooplankton during the various seasons also have not been assessed adequately.

\section{ACKNOWLEDGEMENT}

The authors are indebted to Messrs Djoko Prawoto and Arinardi for procuring the zooplankton data, and to Mr. A.G. Ilahude for his suggestions during the preparation of the manuscript.

\section{REFERENCES}

BILAL, J.; S. WAHJU; MULYONO and ABOEYUWONO 1975. Inventarisasi data perairan Teluk Jakarta. Environment Newsletter 1(1): 3 - 6 .

CHUA THIA ENG 1970. A preliminary study on the plankton of the Ponggol estuary. Hydrobiologia 35(2): $254-272$.

CUSHING, D. H. 1958. The effect of grazing in the primary production: a review. Rapp. et Proc. Verb, des Reunions, Conceil Permanent International pour V Exploration de la Mer 144: 149154.

HUTOMO, M. 1975. Variasi musiman fitoplankton di perairan sekitar Pulau Ayer. Oseanologi di Indonesia 4: 1 - 12.

KASTORO and S. BIROWO 1974. Seasonal changes in sea surface temperature and salinity around Pulau Ayer. Oseanologi di Indonesia 3: 1 - 10.

MCGILL, D. A. 1973. Light and nutrients in the Indian Ocean. In: The biology of the Indian Ocean, ecological studies, analysis and synthesis, vol. 3. (B. ZEITZSCHEL ed.). Springer-Verlag Berlin, Heidelberg, New York : 475-486.

PARSONS, T. R. and J. D. H. STRICKLAND 1963. Discussion of spectrophotometric determination of marine-plant pigments with revised equations for ascertaining chlorophylls and carotenoids. J. Mar. Res. 21(3): 155 - 163.

84 


\section{PELAGIC ENVIRONMENT IN JAKARTA BAY}

PRASENO, D. P. and O. H. ARINARDI 1974. Volume plankton dan penyebarannya di perairan PulauPulau Seribu pada musim-musim timur dan barat. Oseanologi di Indonesia 2: 27 -40.

PUTL and DKI 1973. Laporan tentang hasil survey dan pengumpulan data sampah di DKI Jakarta. Direktorat Teknik Penyehatan Direktorat Jenderal Cipta Karya Departemen PUTL dan Pusat Penelitian Masalah Perkotaan dan Lingkungan DKI Jakarta: $47 \mathrm{pp}+$ annexes.

RICHARDS, F. A. and N. CORWIN 1956. Some oceanographic applications of the solubility of oxygen in sea-water. Limnol. and Oceanogr. 1: 263 - 267.

SOEMARWOTO, O. 1973. Penduduk dan Lingkungan. Perhimpunan Biologi Indonesia. Proceedings, Kongres Biologi I dan Seminar Biologi III, Jakarta 3 - 5 Juli 1973, 1: 15 - 27.

SOERIAATMADJA, R. E. 1956. Seasonal fluctuations in the surface salinity off the north coast of Java. Mar. Res. Indonesia 1: 1-19.

STRICKLAND, J. D. H. 1960. Measuring the production of marine phytoplankton. Fish Res. Board. Canada, Bull. 122: 172 pp.

STRICKLAND, J. D. H. and T. R. PARSONS 1968. A practical handbook of seawater analysis. Fish Res. Board Canada, Bull. 167: 311 pp.

THAM AH KOW 1953. A preliminary study of the physical, chemical and biological characteristics of Singapore Straits. Great Britain Colonial Office, Fish Publ. 1 (4): 65 pp.

TRANTER, D. J. 1973. Seasonal studies of a pelagic ecosystem (meridian $\left.110^{\circ} \mathrm{E}\right)$. In: The biology of the Indian Ocean, ecological studies, analysis and synthesis, vol. 3. (B. ZEIZSCHEL ed.). SpringerVerlag Berlin, Heidelberg, New York : 475-486.

U.S. NAVY HYDROGRAPHIC OFFICE 1959. Instruction manual for oceanographic observations. U.S. Navy Hydrographic Office Publ. 607: 210 pp.

VERSTAPPEN, H. T. 1953. "Djakarta Bay: a geomorphological study on shoreline development". Drukkerij Trio, s'Gravenhage: $101 \mathrm{pp}$.

VERWEY, J. 1929. Depth of coral reefs and penetration of light. With notes on oxygen consumption of corals. Proc. Fourth Pacific Sciences Congress. Batavia - Bandoeng (Java), May - June 1929, vol. II A: 227-299.

WICKSTEAD, J. H. 1965. "An introduction to the study of tropical plankton". Hutchinson Tropical Monographs, Hutchinson \& Co. Ltd. London: $160 \mathrm{pp}$.

WYRTKI, K. 1961. Physical oceanography of the southeast Asian waters. Naga Rep. 2: 195 pp. 